DOI 10.37882/2500-3682.2021.04.21

\title{
ТЕОРИЯ СУБЪЕКТИВНОСТИ Р. ДЕКАРТА
}

\section{THE THEORY OF SUBJECTIVITY P. DESCARTES}

N. Tetenkov

Summary: The article is devoted to the theory of subjectivity of R. Descartes. The article considers the theoretical and methodological foundations of the theory as a concept of subjectivity in general; highlights and analyzes the main provisions of the theory of subjectivity of R. Descartes; analyzes the research works of other authors, examines the inconsistency and specificity of the theory of subjectivity of $R$. Descartes.

Keywords: theory, subjectivity, R. Descartes, justification, subject, cogito, intersubjectivity.
$\mathrm{B}$ настоящее время проблемы субъективности в западноевропейской философии уходят корнями в глубокую древность. Обоснование субъекта в Эйдосе, движущем разумом, логосе позже перерастает в необходимость божественной основы христианского субъекта и содержится в субъекте онтологической зависимости субъекта. Картезианская революция в понимании субъекта также лежит в основе генеалогии проблем субъективности в современной философии. Декарт разорвал связь между природой и чело веком, деонтологизировал субъективность и создал рациональный философский субъект. Определенная изоляция картезианского субъекта от внешнего мира была преодолена английским эмпиризмом, который создал условия для диалектики субъект-объект. И субъект, и объект возникают через рефлексию [1].

Религиозный кризис, вызванный Возрождением, вызвал интерес к культуре и человеку как творцу своего существа. На основе западной культуры сформировался творческий индивидуалистический гуманизм, подчеркивающий сознательный характер человеческой деятельности и акцентирующий внимание на индивидуальных порывах и достижениях. Неокантианцы, начавшие отсчет новой эры с Декарта, полагали, что его акцент на разуме и самосознании требовал принципа доказательства или немедленной уверенности, лежащего в основе философской мысли, что было идентично требованию проверки всех знаний с помощью помощь естественного света разума [3].

Подчеркну, что принцип субъективной надежности также трактовался как ориентация на создание собственных знаний. Однако картезианское «соgito, ergo sum» - «я мыслю, следовательно, я существую» и дей-
Тетенков Николай Борисович

К.ф.н., доцент, Северный (Арктический) федеральный университет имени М.В. Ломоносова, Архангельск tenibo@yandex.ru

Аннотация: Статья посвящена теории субъективности Р. Декарта. В статье рассмотрены теоретико-методологические основы теории как концепции субъективности в целом; выделены и разобраны основные положения теории субъективности Р. Декарта; проанализированы исследовательские работы других авторов, исследована противоречивость и специфика теории субъективности Р. Декарта.

Ключевые слова: теория, субъективность, Р. Декарт, обоснование, субъект, cogito, интерсубъективность.

ствительно новаторский смысл рационалистической эпистемологии поставили ряд проблем. Среди них корреляция аристотелевского cogito, подход Плотина к проблеме субъекта познания и влияние на концепцию cogito Августина, специфика августинцев cogito и роль этого принципа в средневековой философии, своеобразие картезианское cogito и его фундаментальные отличия от августинца [5].

Принцип Cogito который сформулировал Декарт, - это измерение, в котором основание эго как познающего субъекта возникает и приобретает все большее значение. Однако критики Декарта раскрывают несостоятельность картезианского субъекта как основу для установления объективной реальности. Радикальные сомнения успешно справляются со своей функцией, разрушающей объективную реальность. Однако, чтобы восстановить его, Декарту нужна божественная гарантия. Несмотря на то, что картезианский принцип cogito ergo sum получил новые варианты развития в философской мысли следующих столетий, становится очевидной необходимость решения ряда трудностей, неразрывно связанных с принципом философии Декарта [7].

Одна из этих трудностей - проблема интерсубъективности, которую Декарт неявно затронул при разработке принципа Cogito. В философии 20 века вопрос интерсубъективности и проблема другого сознания попрежнему занимают центральное место. Этот предмет активно развивается как в аналитической, так и в феноменологической традиции. Актуальность этой темы по-прежнему высока. Многие критики отмечали неоднородную структуру Cogito, его одновременное присутствие в сфере субъективного и объективного. Принцип «я мыслю» заключен в том, что он является и личным Я 
Декарта и всеобщим Я, сходное по структуре с трансцендентальным субъектом Канта [9].

Подчеркну, что принцип Cogito является фундаментальным для Декарта; фундамент, на котором строятся возможности картезианской философии и науки в целом. Однако в истории философии после Декарта этот принцип подвергается справедливой критике. «Ахиллесова пята» самопринципа Декарта - это его замкнутость [11].

Направимся к идее отца современной европейской субъективности. Имеет смысл сначала определить, что Декарт имеет в виду под мышлением. Критерием включения чего-либо в «мышление» для Картезия было осознание объекта мысли таким, каким он, может быть, мыслим субъектом, то есть Я. «Действительно, Декарт был убежден, что «я мыслю» «примысливает» все, что я мыслю, действует как условие мышления в целом». Таким образом, когда мышление понимается как то, что субъект воспринимает как мыслимое, оно получает довольно широкий спектр возможных интерпретаций. «Что такое мыслящая вещь?» - спрашивает Декарт. А затем он определяет это с помощью процедур сомнения, понимания, утверждения, отрицания, желания, а не желания и обладания воображением и чувствами [2].

Подчеркну, что Декарт анализирует проблему универсалий - объясняет, что универсальные концепции являются творениями разума и не присутствуют в самих вещах. Универсалии формируются разумом на основе сходства отдельных вещей. Декарт настаивал на субъективности чувственных качеств - цветов, вкусов, запахов и т. д. (продолжение рассуждений Демокрита и Галилея по этому поводу, предвосхищая постановку Локком проблемы первичных и вторичных качеств). Размер, фигура, движение, число - это свойства, которые действительно существуют в объектах и могут быть нами понятны. Цвета, вкусы, запахи субъективны, нет оснований рассматривать эти свойства как в самих предметах, они характеризуют то, как человеческое восприятие материальных предметов [12].
Хочу отметить, что Декарт считал, что язык, как неизменная и врожденная субстанция мысли, скрывает универсальные грамматические структуры, порядок вещей и их названия и «дается» каждому акту мышления, и что «cogito» является идеальной единицей сознания [4].

Можно сделать следующие выводы, что учение Декарта оказало значительное влияние на развитие философии и науки. Его идеи повлияли на развитие мировоззрения Спинозы. Картезианцами (последователями Декарта) были Деруа, Ренери, Фонтенель, Клауберг, Беккер, Режис, Рого, Чирнхаузен, Борелли, Стенон, Ла Форж, Кордемуа, Арно, Николь, Гейлинкс, Мальбранш. Физика Декарта один из теоретических источников философии образования. Влияние различных идей Декарта в той или иной форме прослеживается почти во всех великих системах современной рационалистической философии [8].

Декарт понимал, что сознание преднамеренно. Он увидел, что объектные компоненты всех действий последнего также принадлежат сознанию, с той лишь разницей, что он называл их не интенциональными объектами, а идеями. Декарт также понимал, что если мое сознание будет считаться трансцендентным, чтобы существовать абсолютно первичным, аподиктически независимым от моего тела и других объектов внешнего мира, то не только все его действия, но и все идеи, содержащиеся в нем, будут [6].

Как отметил современный философ А.А. Горелов. «Если проводить параллели, следует, конечно, воздерживаться от чрезмерной, неоправданной модернизации философской доктрины Декарта и не делать его трансценденталистом и феноменологом, потому что по сравнению с тем, что мы находим у Гуссерля и его последователей, Декарт описывает структуры трансцендентального еgо в виде прототипа. Основная ошибка соответствующих сравнений состоит в том, что картезианская версия вообще не отражает динамику трансцендентального сознания: исторически Декарт не мог этого сделать» [10].

\section{ЛИТЕРАТУРА}

1. Горелов, А.А. Основы философии. М.: Academia, 2019. 384 c.

2. Гуссерль Э. Кризис европейских наук и трансцендентальная феноменология. Введение в феноменологическую философию. СПб., 2004. С. 113-118.

3. Декарт Р. Возражения некоторых ученых мужей против изложенных выше «Размышлений» // Декарт Р. Соч.: в 2 т. М., 1989-1994. Т. 2. С. 268.

4. Декарт Р. Первоначала философии // Декарт Р. Соч.: В 2 т. М., 1989-1994. Т. 1. С. 315.

5. Декарт Р. Размышления о первой философии // Декарт Р. Собр. соч.: В 2 т. Т. 2. М.. 1989. С. 25.

6. Декарт Р. Размышления о первой философии, в коих доказывается существование Бога и различия между человеческой душой и телом // Соч.: В 2 т. М., 1989-1994. T. 2. С. 16.

7. Доброхотов А.Л. Онтология и этика когито // Встреча с Декартом: Философские чтения, посвященные М.К. Мамардашвили, 1994. М., 1996. С. $31-34,42$.

8. Колесников А.С. Становление проблемы субъекта: от Декарта до современной философии // Формы субъективности в философской культуре XX века. СПб.: Санкт-Петербургское философское общество, 2000. С. 10-25. 
9. Матяш Т.П., Жаров Л.В., Несмеянов Е.Е. Основы философии: Учебник. Ростов н/Д.: Феникс, 2019. 256 с.

10. Мамардашвили М. Картезианские размышления (январь 1981 года). М.: «Прогресс», «Культура», 1993.

11. Мотрошилова Н.В. Идеи І Эдмунда Гуссерля как введение в феноменологию. М., 2003. С. 228-229.

( ) Тетенков Николай Борисович (tenibo@yandex.ru).

Журнал «Современная наука: актуальные проблемы теории и практики»

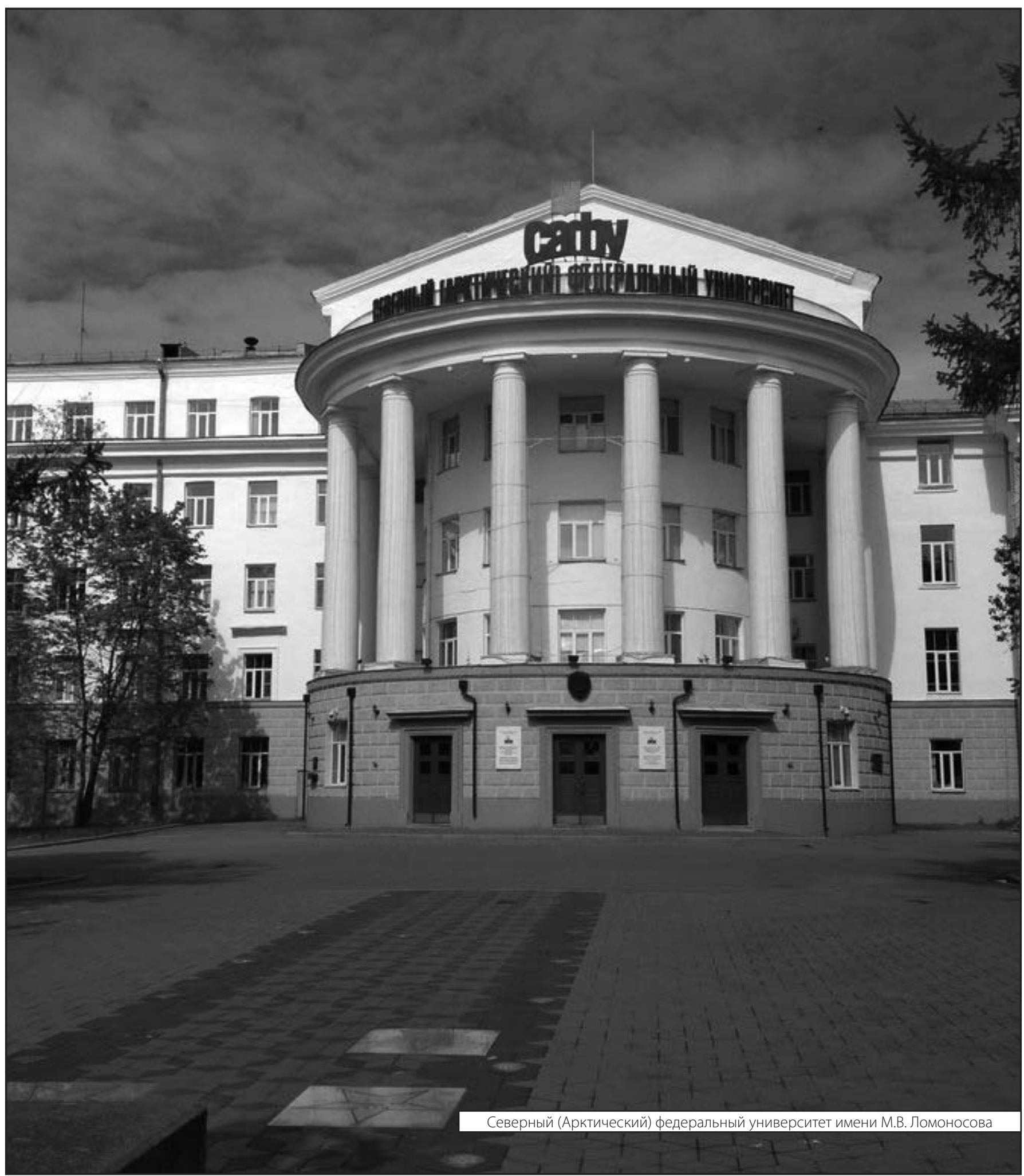

